Int. J. Dev. Biol. 52: 455-462 (2008)

doi: $10.1387 / \mathrm{ijdb} .072527 \mathrm{ss}$

\title{
Regulation of sperm storage and movement in the mammalian oviduct
}

\author{
SUSAN S. SUAREZ* \\ Department of Biomedical Sciences, College of Veterinary Medicine, Cornell University, Ithaca, NY, USA
}

\begin{abstract}
The oviduct plays a vital role in ensuring successful fertilization and normal early embryonic development. The male inseminates many thousands or even millions of sperm, but this alone does not ensure that fertilization will be successful. The female tract, particularly the oviduct, provides filters that select for normal vigorously motile sperm. In conjunction with molecules in the seminal plasma and on sperm, the female tract regulates how and when sperm pass though the tract to reach the site of fertilization. Various regulatory processes control sperm passage into and through the oviduct. In some species, the uterotubal junction opens and closes to regulate when sperm may enter; furthermore, passage through the junction requires certain proteins on the sperm surface. Most of the sperm that manage to enter the oviduct soon become trapped and held in a reservoir. In marsupials and insectivores, this involves trapping sperm in mucosal crypts; while in most other mammalian species, this involves binding sperm to the oviductal epithelium. As the time of ovulation approaches, the sperm in the reservoir undergo capacitation, including motility hyperactivation. Capacitating sperm shed proteins that bind them to the mucosal epithelium, while hyperactivation assists the sperm in pulling off of the epithelium and escaping out of mucosal pockets. The process of sperm release is gradual, reducing chances of polyspermic fertilization. Released sperm may be guided towards the oocyte by secretions of the oviduct, cumulus cells, or oocyte. Hyperactivation likely assists sperm in penetrating the cumulus matrix and is absolutely required for penetrating the oocyte zona pellucida and achieving fertilization.
\end{abstract}

KEY WORDS: sperm, fallopian tube, uterine tube, oviduct

The oviduct consists of three segments, each with different functions: the uterotubal junction, the isthmus, and the ampulla. The uterotubal junction provides a barrier to infectious microbes that might enter the oviduct from the uterus. It also regulates which sperm may enter and when. The isthmus serves as a sperm storage organ and the ampulla provides an environment conducive to fertilization and early embryonic development. The movements of sperm are regulated by these three segments in different ways so as to fulfill those functions.

The uterotubal junction regulates sperm movement from uterus to oviduct

The anatomy of the uterotubal junction indicates that it is constructed to restrict entry of infectious organisms and leukocytes from the uterus and to regulate entry of sperm (Fig. 1A). In many species, mucosal folds fill most of the lumen and these folds can further occlude the lumen by contraction of smooth muscle in the wall and/or by fluid engorgement of the connective tissue in the wall (Wrobel et al., 1993; Hafez and Black 1969). In the cow, mucosal folds form cul-de-sacs that face back towards the uterus (Yaniz et al., 2006).

In the mouse, the junction is patent shortly after coitus, but tightly closed about an hour later (Zamboni 1972; Suarez, 1987). Electron micrographs reveal close apposition of epithelium and interdigitation of microvilli (Zamboni 1972). Very little is known of the signals that regulate smooth muscle contraction or wall fluid engorgement to open and close the junction.

In some species, the narrow lumen of the uterotubal junction is

Abbreviations frequently used in this paper: ADAM, a disintegrin and metalloprotease; BSP, bovine seminal plasma; LTL, lotus teragonolobus; tACE, testis-specific angiotensin converting enzyme.

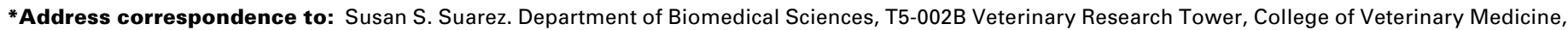
Cornell University, Ithaca, NY 14853, USA. e-mail: sss7@cornell.edu
}

Published online: 4th July 2008

0214-6282/2008/\$35.00

(C) UBC Press

Printed in Spain 
filled with mucus. Mucus has been found in the uterotubal junction in humans (Jansen, 1980), as well as in rabbits (Jansen, 1978; Jansen and Bajpai, 1982), pigs (Hunter, 2002; Suarez et al., 1990), and dairy cattle (Suarez et al., 1997). In humans, mucus is produced primarily during the periovulatory period and is thought to serve as a selective conduit for sperm (Jansen, 1980).

Although the uterotubal junction may become more patent during estrus or when stimulated by coitus, sperm may not readily pass through it unless certain proteins are present on the sperm head plasma membrane. Male mice that are null mutants for the genes encoding ADAM2 (Cho etal., 1998), calmegin (lkawa etal., 1997; Yamagata et al., 2002), or testis-specific angiotensin converting enzyme (tACE) (Hagaman et al., 1998, Krege et al., 1995) are infertile because their sperm cannot pass through the uterotubal junction nor bind to the zona pellucida. In these null mutants, both the motility and morphology of the sperm appear normal. ADAM2 (also known as fertilin $\beta$ ) is localized on the plasma membrane overlying the acrosome on mature sperm (Cho et al., 1998). Null mutant sperm for ADAM2 also have abnormally low levels of ADAM3 (cyritestin) as well as other ADAMs on mature sperm (Kim et al., 2006; Nishimura et al., 2007). In the case of calmegin, this is a chaperone protein, which is active in testicular spermatogenic cells where it lies in the lumen of rough endoplasmic reticulum and assists in the proper folding of some nascent polypeptides destined for sperm plasma membranes. Male mice that are null mutants for calmegin lack ADAM3 on mature sperm (Yamaguchi et al., 2006). In the case of tACE null mutants, there is strong evidence that the missing tACE normally acts to release GPI-anchored proteins from the sperm plasma membrane (Kondoh et al., 2005; Metayer et al., 2002). Male mice that are null mutants for tACE show abnormal distribution of ADAM3 in sperm membranes (Yamaguchi et al., 2006). Altogether, these null phenotypes implicate ADAM3 in providing passage of sperm through the uterotubal junction, although this remains to be tested and other ADAMs may be involved instead or as well. The role of ADAMs in enabling sperm to pass through the uterotubal junction may be to allow sperm to gain footholds on the wall lining the junction and thus move ahead by sticking lightly to the epithelium.

\section{Formation of the oviductal sperm storage reservoir}

In mammals, sperm are held in a storage reservoir in the oviduct until the time of ovulation draws near. In marsupial mammals and some insectivores (Bedford et al., 1999; Bedford et al., 1997a; Bedford et al., 1997b; Taggart, 1994), sperm are stored in special mucosal crypts or bulbous pockets. In some cases the sperm appear to be held in the crypts by suppression of flagellar motility (Bedford and Breed, 1994).

In contrast to the marsupials and insectivores, most other species of mammals create an oviductal sperm storage reservoir by binding the sperm to the epithelial surface (Harper, 1973, Hunter, 1981; Hunter and Nichol, 1983; Overstreet and Cooper, 1978; Suarez, 1987; Wilmut and Hunter, 1984; Yanagimachi and Chang, 1963). There are no specific structures like crypts; however, many of the bound sperm are found down in pockets formed by mucosal folds (Fig. 1B). Binding sperm to the epithelium plays a role in preserving sperm fertility while they are stored and also serves to reduce incidence of polyspermic fertilization by releasing sperm very gradually during the periovulatory period. While oocytes have one or more mechanisms for blocking polyspermy (Hedrick, 2007; Wortzman-Show etal., 2007), further protection from polyspermy is provided by the gradual release of sperm from the reservoir. In the pig, when sperm numbers were artificially increased at the site of fertilization, the incidence of polyspermy was increased (Day and Polge, 1968; Hunter, 1973; Hunter and Leglise, 1971; Polge et al., 1970).

\section{Identification of oviduct binding proteins on sperm}

Carbohydrate moieties are key components of oviductal receptors for sperm. Specific mono- and oligo-saccharides have been shown to competitively inhibit sperm binding to oviductal epithelium in various species (hamster, DeMott et al., 1995; horse, Dobrinski et al., 1996a; pig, Green et al., 2001, Wagner et al., 2002).

Competitive binding inhibition assays identified fucose, particularly in the trisaccharide Lewis-a, as the key component of the oviductal receptor for bull sperm (Lefebvre et al., 1997; Suarez et al., 1998). Affinity purification using Lewis-a as the trap identified PDC109 (also known as BSPA1/A2) as a protein responsible for binding bull sperm to oviductal epithelium (Gwathmey et al., 2003; Ignotz et al., 2001). PDC109 is a small (approximately $16 \mathrm{kDa}$ ) acidic, heparin-binding protein, consisting primarily of two fibronectin type II domains. It is secreted by the seminal vesicles and coats the periacrosomal plasma membrane of sperm by associating with membrane choline phospholipids (Desnoyers and Manjunath, 1992; Muller et al., 1998; Ramakrishnan et al., 2001). Epididymal bull sperm bind oviductal epithelium in very low numbers, but when they are coated with PDC109 purified from seminal plasma, their binding increases to the level of ejaculated bull sperm (Gwathmey et al., 2003).

PDC109 is a member of the bovine seminal plasma (BSP) family of proteins. Two other proteins in the family, BSP30K and BSPA3, have also been shown to dramatically enhance binding of epididymal bull sperm to epithelium (Gwathmey et al., 2006). Like PDC109, these are also seminal vesicles secretions that bind heparin and coat the sperm head over the acrosomal region; however, they are present in seminal plasma at only about 1/10 the level of PDC109 (Nauc and Manjunath, 2000). Each one alone is sufficient to raise binding to the level of ejaculated sperm, so it is unlikely that they are required together in a complex. The redundancy of oviduct binding proteins, likely arising through gene duplication, implies that formation of the reservoir is key to reproductive success. Proteins homologous to the BSPs have been identified in several other species. Some of the homologs have also been demonstrated to bind heparin and membrane phospholipids (Calvete et al., 1997; Fan et al., 2006; Leblond et al., 1993).

Binding of epididymal bull sperm to epithelium does occur at a low level. This could be a nonspecific interaction or it could be due to more recently discovered members of the BSP family predicted to be expressed in the epididymis (Fan et al., 2006). In other species, epididymal homologs of the BSP family may be primarily responsible for binding sperm to oviductal epithelium. BSP homologs in the mouse are identified from the EST database as epididymal proteins (Fan et al., 2006). Hamster 

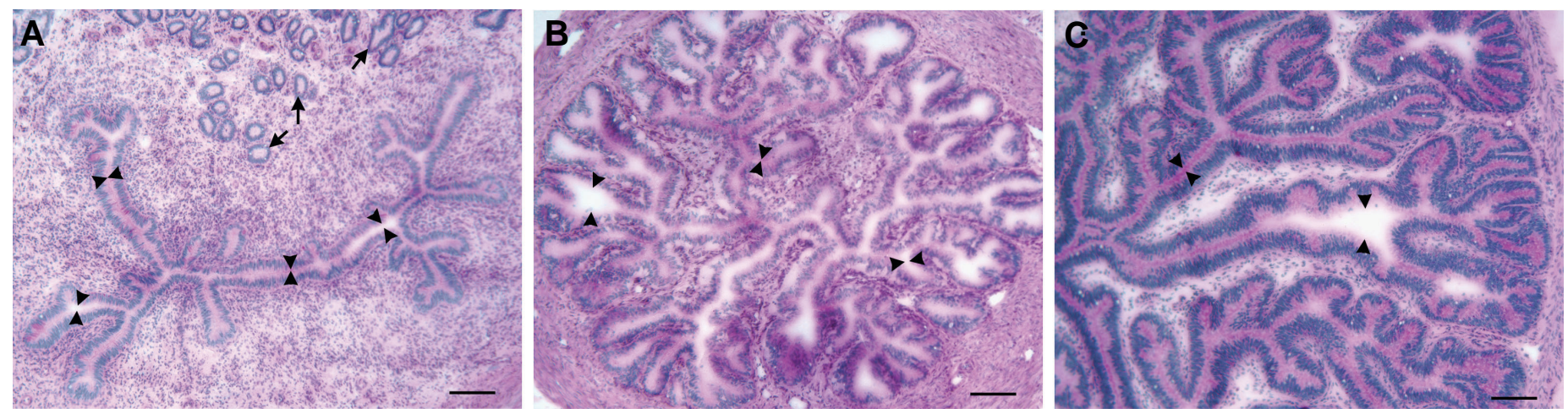

Fig. 1. Frozen cross sections of the uterotubal junction (A), isthmus (B), and ampulla (C) of a preovulatory bovine oviduct, stained with Periodic Acid Schiff to show mucopolysaccharides and with hematoxylin to stain nuclei (see Suarez et al., 1997). The oviduct was frozen for sectioning to avoid shrinkage associated with embedding tissue in plastic or paraffin. All images were taken at the same magnification (bar, $100 \mu \mathrm{m}$ ). Arrows indicate uterine glands in the wall of the uterotubal junction, which open into the uterine lumen. Arrowheads indicate the oviductal lumen, much of which is as narrow as a sperm head and filled with mucus. Only about half of the diameter of the ampulla is shown. The bovine oocyte, which measures about $125 \mu \mathrm{m}$, would take up only a small area of the lumen.

epididymal sperm infused into oviducts bind to the epithelium (DeMott et al., 1995), indicating that hamster homologs may be expressed in testis or epididymis.

\section{Identification of oviductal receptors for sperm proteins}

Oviductal receptors for the BSP proteins were isolated from extracts of bovine apical plasma membrane epithelium using purified BSP proteins as traps. They were identified as four members of the annexin (ANXA1,-2,-4,-5) family of proteins (Ignotz et al., 2007). Antibodies to each of the ANXAs localized them to the apical surfaces of mucosal epithelium in sections of oviduct and also inhibited sperm binding to explants of oviductal epithelium. Western blots confirmed the presence of ANXAs in apical plasma membranes. Because fucose had been determined to be a critical component of the bovine oviductal receptor, the ANXAs were immunoprecipitated from solubilized apical plasma membranes and probed with Lotus tetragonolobus (LTL) lectin to verify the presence of fucose (Ignotz et al., 2007). Thus, these ANXAs are strong candidates for the sperm receptors on bovine oviductal epithelium.

ANXAs comprise a large family of proteins whose functions are poorly understood. They have been localized within cells, in secretions, or on cell surfaces (Rescher and Gerke, 2007). Although ANXAs lack signal peptides to direct them to the cell surface, other mechanisms have been identified that transport ANXAs from cytoplasm to the plasma membrane (Deora et al., 2004). ANXA4 and ANXA5 have been localized to the apical regions of rat oviductal epithelium (Kaetzel et al., 1989), while ANXA1 was detected in extracts of rabbit oviduct epithelium (Tsao et al., 1995). ANXA1 and ANXA2 are associated with cilia of quail oviduct epithelial cells (Chailley and Pradel, 1992). Cell surface ANXA2 mediates cell adhesion between lymphocytes and endothelial cells (Tressler et al., 1993), which might occur via a similar mechanism as that of binding sperm to oviductal epithelium.

ANXA5, conjugated with fluorescein, binds to the acrosomal region of bull and boar sperm (Chaveiro et al., 2007; Gadella and Harrison, 2002). Although ANXA5 is commonly used as a probe to detect cells undergoing apoptosis, other markers of apoptosis showed that ANXA5-labeled boar sperm were not apoptotic, indicating that normal, live boar sperm can bind ANXA5 (Gadella and Harrison, 2002).

Interestingly, ANXA1 is secreted in fairly high amounts by the human prostate gland into the seminal plasma (Christmas et al., 1991). It is not known whether human sperm carry the seminal plasma ANXAs into the oviduct, where they might be replaced by the ANXAs on the oviductal epithelium.

Whereas BSPs have been shown to work individually to enhance sperm binding to epithelium, it is not yet known whether each ANXA alone can act as a receptor for sperm.

The involvement of multiple species of BSPs and ANXAs in sperm binding underscores the importance of holding sperm in the oviductal reservoir. During evolution, when gene duplication occurs and multiple closely related versions of genes are maintained in the genome, all of which actively produce protein products, it is likely that these gene products serve important functions and provide reproductive advantages to the individuals that produce them. The differences among the duplicated gene products can ensure that the system is functional under a variety of conditions. An example of this is isoenzymes, which provide catalytic activity under a broad range of conditions (Campbell and Heyer, 2003). The BSP proteins differ from each other in distribution of surface electrostatic charge (Gwathmey et al., 2006). This bestows the BSPs with different binding affinities for the surface of sperm on one face of the molecule and for the oviductal epithelium on the opposite face. Similarly, the various ANXAs on the oviductal epithelium must have different binding affinities and kinetics for the BSPs on sperm. Thus, the duplication of BSP and ANXA proteins on the sperm side and the oviduct side of the interaction, respectively, can provide a finely tuned regulatory system to ensure that sperm are held and kept fertile in the reservoir and then released gradually at the appropriate time to ensure that fertilization (but not polyspermy) takes place.

\section{Preservation of sperm fertility during storage}

Sperm binding to epithelium somehow preserves their fertility during storage. Sperm incubated with epithelium in vitro remain viable longer than when they are incubated in medium alone 
(Suarez et al., 1990; Pollard et al., 1991; Ellington et al., 1993; Kawakami et al., 2001). Viability of sperm can be extended by incubating them with vesicles prepared from the apical membranes of isthmic epithelium, indicating that the epithelium alone can produce the effect (Dobrinski etal., 1996b; Smith and Nothnick, 1997; Gwathmey et al., 2006; Murray and Smith, 1997). Equine sperm binding to oviductal epithelium or membrane vesicles maintain low levels of cytoplasmic $\mathrm{Ca}^{2+}$, compared to free-swimming sperm or sperm incubated with vesicles made from kidney membranes (Dobrinski et al., 1997; Dobrinski et al., 1996b). Human and equine sperm incubated with membrane vesicles capacitate more slowly than sperm incubated in capacitating medium alone (Dobrinski et al., 1997; Murray and Smith 1997). Possibly, viability is maintained by preventing capacitation and its concomitant rise in cytoplasmic $\mathrm{Ca}^{2+}$. The mechanism for preventing rises of cytoplasmic $\mathrm{Ca}^{2+}$ in sperm are not known, but one suggestion is that catalase, which has been detected in the bovine oviduct, serves to protect against peroxidative damage to the sperm membranes, perhaps preventing increased inward leakage of $\mathrm{Ca}^{2+}$ (Lapointe et al., 1998).

The oviductal binding protein on bull sperm, PDC109, probably acts to stabilize sperm membranes. PDC109 reduces membrane fluidity and immobilizes cholesterol in phospholipid membranes, including those of epididymal sperm (Greube et al., 2001; Muller et al., 2002). PDC109 could also contribute to membrane stability by inhibiting the activity of phospholipase $\mathrm{A}_{2}$ (Manjunath et al., 1994; Soubeyrand and Manjunath, 1997). Thus, PDC109 may play a role in preserving bull sperm fertility while they are stored in the reservoir.

\section{Release of sperm from the reservoir}

Theoretically, either a loss of binding sites on the oviductal epithelium or a change in sperm could be responsible for release of sperm from the reservoir. Changes in the hormonal state of oviductal epithelium related to impending ovulation were not seen to affect the density of binding sites for sperm in a number of species (Suarez etal., 1991a; Lefebvre et al., 1995;Thomas etal., 1994). On the other hand, there is strong evidence that changes in sperm that are associated with capacitation are responsible for releasing sperm.

Loss of oviduct-binding proteins from the sperm plasma membrane, or their modification, could reduce affinity of sperm for the oviductal epithelium. Capacitated bull sperm show reduced binding to oviductal epithelium as well as to the carbohydrate ligand involved in sperm binding (Ignotz et al., 2001; Revah et al., 2000). This can be accounted for by a shedding of the adsorbed seminal plasma protein PDC109 from the sperm head during capacitation,

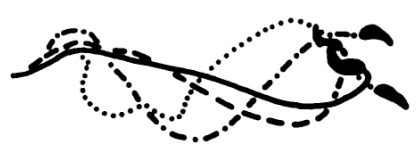

activated

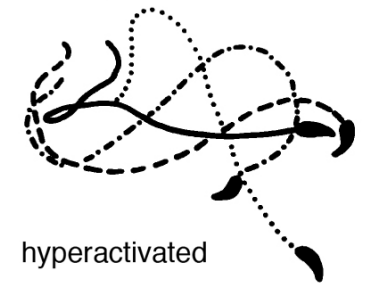

Fig. 2. Movement patterns of activated and hyperactivated mouse sperm (modified from Suarez and Dai, 1992). because binding can be restored in capacitated sperm by adding back purified PDC109 to sperm (Gwathmey et al., 2003).

Heparin is used to capacitate bull sperm in vitro (GalantinoHomer et al., 1997; Parrish et al., 1988). The BSP proteins PDC109, BSP30K, and BSPA3 possess heparin-binding sites(Calvete et al., 1999; Chandonnet et al., 1990; Wah et al., 2002) and incubation with heparin has been shown to remove PDC109 from sperm (Gwathmey et al., 2003). Addition of heparin to bull sperm bound to cultured oviductal epithelium enhances their release (Bosch et al., 2001). Parrish and colleagues (Parrish et al., 1989) showed that heparin-like molecules account for the capacitating activity of bovine oviduct fluid in vitro. Thus, increased secretion of glycosaminoglycans into oviduct fluid late in estrus could release sperm from the reservoir. It is interesting that ANXAs, the oviductal receptors for the BSPs, also bind heparin (Ishitsuka et al., 1998; Shao et al., 2006), suggesting that heparin (or a similar glycosaminoglycan) could enhance sperm release by two mechanisms: inducing loss of BSPs from sperm and interfering with binding of BSPs to ANXAs.

During capacitation, sperm also become hyperactivated. Hyperactivated sperm show increased flagellar bend amplitudes, usually on one side of the flagellum, which causes the flagellum to beat asymmetrically (Suarez and Ho, 2003)(Fig. 2). The power of the increased bend amplitude can provide the force necessary for overcoming the attraction between sperm and epithelium. Oviducts removed from mated female mice can be transilluminated in order to examine the behavior of sperm within the reservoir. Under these conditions, hyperactivated sperm can be seen yanking themselves free from the oviductal epithelium. It was noted that only hyperactivated sperm detached from the epithelium (DeMott and Suarez, 1992).

In summary, during capacitation, a combination of shedding extrinsic proteins and hyperactivation likely serves to free sperm from the oviductal epithelium. The epithelium may play a role in sperm release by secreting capacitation factors.

\section{Sperm movement after release from the oviductal stor- age reservoir}

As discussed above, hyperactivation assists sperm in escaping from the reservoir. Hyperactivation assists sperm in other ways as well. Sperm that are hyperactivated are better able to penetrate viscoelastic substances (Quill et al., 2003; Suarez and Dai, 1992; Suarez et al., 1991). Mucus fills the uterotubal junction and extends well into the isthmus in humans (Jansen, 1980), rabbits (Jansen, 1978), pigs (Suarez et al., 1991a), and cows (Suarez et al., 1997); therefore, hyperactivation may assist sperm in swimming through the mucus to escape from the isthmus.

Observations of sperm moving within the mouse oviduct indicate that hyperactivation also endows sperm with greater flexibility for turning around in the pockets between mucosal folds so as to move out into the center of the lumen (Suarez and Osman, 1987).

Hyperactivation may also play a role in chemotaxis. Sperm are equipped with a mechanism for turning towards the oocyte in response to chemotactic factors; that is, they can switch back and forth between symmetrical flagellar beating and the asymmetrical flagellar beating of hyperactivation. Hyperactivation is reversible (Suarez et al., 1987), which enables sperm to alternate between 
turning and swimming straight ahead. Mammalian sperm, particularly human sperm, have been reported to turn towards, or accumulate in, a gradient of follicular fluid (Cohen-Dayag et al., 1995; Fabro et al., 2002; Ralt et al., 1994) or medium conditioned by cumulus cells or oocytes (Sun et al., 2005).

Odorant receptors have been localized to a spot in the base of the flagellum or to the flagellar midpiece of human (Spehr et al., 2003), canine (Vanderhaeghen et al., 1993), and rat sperm (Walensky et al., 1995). Placing human sperm in a gradient of the odorant bourgeonal caused a fraction of them to orient into the gradient and triggered rises in cAMP and $\mathrm{Ca}^{2+}$ (Spehr et al., 2004). However, odorant-like molecules have not yet been identified in follicular fluid or secretions of the cumulus cells or oocytes.

Despite these intriguing reports of chemotaxis, a chemotactic agent has yet to be identified with certainty in the oviduct, follicular fluid, cumulus matrix, or oocyte. Furthermore, in vitro, only a small percentage of sperm (usually less than 10\%) are seen to respond chemotactically to physiological secretions, making the identification of active agents difficult (reviewed by $M$ Eisenbach in this volume and Kaupp et al., 2007).

Because hyperactivation occurs in the caudal isthmus, which is a considerable distance from the site of fertilization, sperm may already be hyperactivated when they come under the influence of chemotactic signals. Chemotaxis may therefore involve modulation of hyperactivation to turn sperm towards the oocyte. In the mouse, the cumulus mass fills the ampulla and thus makes an easy target for sperm. In this case, sperm may require guidance to reach oocytes within the large cumulus mass. In humans, cattle, and other large species, the cumulus mass occupies only a small area in the maze-like lumen of the ampulla (Fig. 1C). In these species, sperm might need additional guidance to reach the cumulus mass within the ampulla.

Once sperm reach the cumulus mass, they are usually obliged to swim through the cumulus matrix to reach the oocyte zona pellucida. The matrix is viscoelastic, primarily due to long flexible molecules of hyaluronic acid, which are linked by proteins (Zhuo et al., 2001; Fulop et al., 2003; Salustri et al., 2004). Whereas hyperactivation would assist sperm in penetrating the matrix, the presence of a hyaluronidase on the sperm surface (Kim et al., 2005) must aid in the process. Sperm penetration of the cumulus matrix is reviewed by $\mathrm{T}$. Baba in this volume.

Upon reaching the zona pellucida, sperm require hyperactivation in order to penetrate it. When hyperactivation was blocked in capacitated, acrosome-reacted hamster sperm bound to the zona, they were unable to penetrate it (Stauss etal., 1995). Sperm from male mice that are null mutants for CatSper genes and cannot hyperactivate also cannot penetrate the zona (Quill et al., 2003; Ren et al., 2001).

\section{Conclusions}

Although many thousands, or even millions, of sperm are inseminated, this alone does not ensure that sperm will pass into and through the oviduct to reach the oocyte. The ascent of sperm is regulated by the female and successful sperm must be equipped with specific proteins for passing into the oviduct and remaining viable until ovulation. Sperm must also be able to hyperactivate in order to release themselves from the storage reservoir and to penetrate the cumulus matrix and oocyte zona pellucida. The oocyte, cumulus, or some secretion of the female tract may also provide chemotactic guidance to sperm.

\section{Acknowledgements}

The author's recent work reported in this review was supported by National Research Initiative Competitive Grant no. 2004-35203-14952 from the USDA Cooperative State Research, Education, and Extension Service and MCB 0421855 from the National Science Foundation.

\section{References}

BEDFORD, J.M. and BREED, W.G. (1994). Regulated storage and subsequent transformation of spermatozoa in the fallopian tubes of an Australian marsupial, Sminthopsis crassicaudata. Biol Reprod 50: 845-54.

BEDFORD, J.M., MOCK, O.B., NAGDAS, S.K., WINFREY, V.P. and OLSON, G.E. (1999). Reproductive features of the eastern mole (Scalopus aquaticus) and star-nose mole (Condylura cristata). J Reprod Fertil 117: 345-53.

BEDFORD, J.M., MOCK, O.B. and PHILLIPS, D.M. (1997a). Unusual ampullary sperm crypts, and behavior and role of the cumulus oophorus, in the oviduct of the least shrew, Cryptotis parva. Biol Reprod 56: 1255-67.

BEDFORD, J.M., MORI, T. and ODA, S. (1997b). Ovulation induction and gamete transport in the female tract of the musk shrew, Suncus murinus. JReprod Fertil 110: $115-25$.

BOSCH, P., DE AVILA, J.M., ELLINGTON, J.E. and WRIGHT, R.W., JR. (2001). Heparin and $\mathrm{Ca} 2+$-free medium can enhance release of bull sperm attached to oviductal epithelial cell monolayers. Theriogenology 56: 247-60.

CALVETE, J.J., CAMPANERO-RHODES, M.A., RAIDA, M. and SANZ, L. (1999). Characterisation of the conformational and quaternary structure-dependent heparin-binding region of bovine seminal plasma protein PDC-109. FEBS Lett 444: $260-4$.

CALVETE, J.J., RAIDA, M., GENTZEL, M., URBANKE, C., SANZ, L. and TOPFERPETERSEN, E. (1997). Isolation and characterization of heparin- and phosphorylcholine-binding proteins of boar and stallion seminal plasma. Primary structure of porcine pB1. FEBS Lett 407: 201-6.

CAMPBELL A.M. and HEYER, L.J. (2003). Discovering Genomics, Proteomics, and Bioinformatics. San Francisco: Benjamin Cummings. $351 \mathrm{pp}$.

CHAILLEY, B. and PRADEL, L.A. (1992). Immunodetection of annexins 1 and 2 in ciliated cells from quail oviduct. Biol Cel/75: 45-54.

CHANDONNET, L., ROBERTS, K.D., CHAPDELAINE, A. and MANJUNATH, P. (1990). Identification of heparin-binding proteins in bovine seminal plasma. Mol Reprod Dev 26: 313-8.

CHAVEIRO, A., SANTOS, P. and DA SILVA, F.M. (2007). Assessment of sperm apoptosis in cryopreserved bull semen after swim-up treatment: a flow cytometric study. Reprod Domest Anim 42: 17-21.

CHO, C., BUNCH, D.O., FAURE, J.E., GOULDING, E.H., EDDY, E.M., PRIMAKOFF, P. and MYLES, D.G. (1998). Fertilization defects in sperm from mice lacking fertilin beta. Science 281: 1857-9.

CHRISTMAS, P., CALLAWAY, J., FALLON, J., JONES, J. and HAIGLER, H.T. (1991). Selective secretion of annexin 1, a protein without a signal sequence, by the human prostate gland. J Biol Chem 266: 2499-507.

COHEN-DAYAG, A., TUR-KASPA, I., DOR, J., MASHIACH, S. and EISENBACH, M. (1995). Sperm capacitation in humans is transient and correlates with chemotactic responsiveness to follicular factors. Proc Natl Acad Sci USA 92: 11039-43.

DAY, B.N. and POLGE, C. (1968). Effects of progesterone on fertilization and egg transport in the pig. $J$ Reprod Fertil17: 227-30.

DEMOTT, R.P., LEFEBVRE, R. and SUAREZ, S.S. (1995). Carbohydrates mediate the adherence of hamster sperm to oviductal epithelium. Biol Reprod52: 1395403.

DEMOTT, R.P. and SUAREZ, S.S. (1992). Hyperactivated sperm progress in the mouse oviduct. Biol Reprod 46: 779-85.

DEORA, A.B., KREITZER, G., JACOVINA, A.T. and HAJJAR, K.A. (2004). An annexin 2 phosphorylation switch mediates p11-dependent translocation of annexin 2 to the cell surface. J Biol Chem 279: 43411-8.

DESNOYERS, L. and MANJUNATH, P. (1992). Major proteins of bovine seminal 
plasma exhibit novel interactions with phospholipid. J Bio/ Chem267: 10149-55.

DOBRINSKI, I., IGNOTZ, G.G., THOMAS, P.G. and BALL, B.A. (1996a). Role of carbohydrates in the attachment of equine spermatozoa to uterine tubal (oviductal) epithelial cells in vitro. Am J Vet Res 57: 1635-9.

DOBRINSKI, I., SMITH, T.T., SUAREZ, S.S. and BALL, B.A. (1997). Membrane contact with oviductal epithelium modulates the intracellular calcium concentration of equine spermatozoa in vitro. Biol Reprod56: 861-9.

DOBRINSKI, I., SUAREZ, S.S. and BALL, B.A. (1996b). Intracellular calcium concentration in equine spermatozoa attached to oviductal epithelial cells in vitro. Biol Reprod 54: 783-8.

ELLINGTON, J.E., BALL, B.A., BLUE, B.J. and WILKER, C.E. (1993). Capacitationlike membrane changes and prolonged viability in vitro of equine spermatozoa cultured with uterine tube epithelial cells. Am J Vet Res 54: 1505-10.

FABRO, G., ROVASIO, R.A., CIVALERO, S., FRENKEL, A., CAPLAN, S.R., EISENBACH, M. and GIOJALAS, L.C. (2002). Chemotaxis of capacitated rabbit spermatozoa to follicular fluid revealed by a novel directionality-based assay. Biol Reprod 67: 1565-71.

FAN, J., LEFEBVRE, J. and MANJUNATH, P. (2006). Bovine seminal plasma proteins and their relatives: A new expanding superfamily in mammals. Gene 375: 63-74.

FULOP, C., SZANTO, S., MUKHOPADHWAY, D., BARDOS, T., KAMATH, R.V. RUGG, M.S., DAY, A.J., SALUSTRI, A., HASCALL, V.C., GLANT, T.T., and MIKECA, K. (2003) Impaired cumulus mucification and female sterility in tumor necrosis factor-induced protein-6 deficient mice. Development130: 2253-2261.

GADELLA, B.M. and HARRISON, R.A. (2002). Capacitation induces cyclic adenosine 3',5'-monophosphate-dependent, but apoptosis-unrelated, exposure of aminophospholipids at the apical head plasma membrane of boar sperm cells. Biol Reprod 67: 340-50.

GALANTINO-HOMER, H.L., VISCONTI, P.E. and KOPF, G.S. (1997). Regulation of protein tyrosine phosphorylation during bovine sperm capacitation by a cyclic adenosine 3'5'-monophosphate-dependent pathway. Biol Reprod56: 707-19.

GREEN, C.E., BREDL, J., HOLT, W.V., WATSON, P.F. and FAZELI, A. (2001). Carbohydrate mediation of boar sperm binding to oviductal epithelial cells in vitro. Reproduction 122: 305-15.

GREUBE, A., MULLER, K., TOPFER-PETERSEN, E., HERRMANN, A. and MULLER, P. (2001). Influence of the bovine seminal plasma protein PDC-109 on the physical state of membranes. Biochemistry 40: 8326-34.

GWATHMEY, T.M., IGNOTZ, G.G., MUELLER, J.L., MANJUNATH, P. and SUAREZ, S.S. (2006). Bovine seminal plasma proteins PDC-109, BSP-A3, and BSP-30kDa share functional roles in storing sperm in the oviduct. Biol Reprod75: 5017.

GWATHMEY, T.M., IGNOTZ, G.G. and SUAREZ, S.S. (2003). PDC-109 (BSP-A1/ A2) promotes bull sperm binding to oviductal epithelium in vitro and may be involved in forming the oviductal sperm reservoir. Biol Reprod69: 809-15.

HAFEZ, E.S.E., and BLACK, D.L. (1969). The mammalian uterotubal junction. In 'The Mammalian Oviduct: Comparative Biology and Methodology'. (Eds E.S.E. Hafez and R.J. Blandau.) pp. 85-128. (The University of Chicago Press: Chicago.)

HAGAMAN, J.R., MOYER, J.S., BACHMAN, E.S., SIBONY, M., MAGYAR, P.L., WELCH, J.E., SMITHIES, O., KREGE, J.H. and O'BRIEN, D.A. (1998). Angiotensin-converting enzyme and male fertility. Proc Nat/ Acad Sci USA 95: 25527.

HARPER, M.J. (1973). Relationship between sperm transport and penetration of eggs in the rabbit oviduct. Biol Reprod 8: 441-50.

HEDRICK, J.L. (2007). A comparative analysis of molecular mechanisms for blocking polyspermy: identification of a lectin-ligand binding reaction in mammalian eggs. Soc Reprod Fertil Supp/63: 409-19.

HUNTER, R.H. (1973). Polyspermic fertilization in pigs after tubal deposition of excessive numbers of spermatozoa. J Exp Zoo/183: 57-63.

HUNTER, R.H. (1981). Sperm transport and reservoirs in the pig oviduct in relation to the time of ovulation. J Reprod Ferti/63: 109-17.

HUNTER, R.H. (2002). Vital aspects of Fallopian tube physiology in pigs. Reprod Domest Anim 37: 186-90.

HUNTER, R.H. and LEGLISE, P.C. (1971). Polyspermic fertilization following tubal surgery in pigs, with particular reference to the role of the isthmus. $J$ Reprod Fertil 24: 233-46
HUNTER, R.H. and NICHOL, R. (1983). Transport of spermatozoa in the sheep oviduct: preovulatory sequestering of cells in the caudal isthmus. $J$ Exp Zool 228: 121-8.

IGNOTZ, G.G., CHO, M.Y. and SUAREZ, S.S. (2007). Annexins Are Candidate Oviductal Receptors for Bovine Sperm Surface Proteins and Thus May Serve to Hold Bovine Sperm in the Oviductal Reservoir. Biol Reprod.

IGNOTZ, G.G., LO, M.C., PEREZ, C.L., GWATHMEY, T.M. and SUAREZ, S.S. (2001). Characterization of a fucose-binding protein from bull sperm and seminal plasma that may be responsible for formation of the oviductal sperm reservoir. Biol Reprod64: 1806-11.

IKAWA, M., WADA, I., KOMINAMI, K., WATANABE, D., TOSHIMORI, K., NISHIMUNE, Y. and OKABE, M. (1997). The putative chaperone calmegin is required for sperm fertility. Nature 387: 607-11.

ISHITSUKA, R., KOJIMA, K., UTSUMI, H., OGAWA, H. and MATSUMOTO, I. (1998). Glycosaminoglycan binding properties of annexin IV, V, and VI. J Biol Chem 273: 9935-41.

JANSEN, R.P. (1978). Fallopian tube isthmic mucus and ovum transport. Science 201: 349-51

JANSEN, R.P. (1980). Cyclic changes in the human fallopian tube isthmus and their functional importance. Am J Obstet Gyneco/136: 292-308.

JANSEN, R.P. and BAJPAI, V.K. (1982). Oviduct acid mucus glycoproteins in the estrous rabbit: ultrastructure and histochemistry. Biol Reprod26: 155-68.

KAETZEL, M.A., HAZARIKA, P. and DEDMAN, J.R. (1989). Differential tissue expression of three $35-\mathrm{kDa}$ annexin calcium-dependent phospholipid-binding proteins. J Biol Chem 264: 14463-70.

KAUPP, U.B., KASHIKAR, N.D. and WEYAND, I. (2007). Mechanisms of Sperm Chemotaxis. Annu Rev Physiol.

KAWAKAMI, E., KASHIWAGI, C., HORI, T. and TSUTSUI, T. (2001). Effects of canine oviduct epithelial cells on movement and capacitation of homologous spermatozoa in vitro. Anim Reprod Sci68: 121-31.

KIM, E., BABA, D., KIMURA, M., YAMASHITA, M., KASHIWABARA, S. and BABA, T. (2005). Identification of a hyaluronidase, Hyal5, involved in penetration of mouse sperm through cumulus mass. Proc Nat/ Acad Sci USA 102: 18028-33.

KIM, T., OH, J., WOO, J.M., CHOI, E., IM, S.H., YOO, Y.J., KIM, D.H., NISHIMURA, $\mathrm{H}$. and $\mathrm{CHO}$, C. (2006). Expression and relationship of male reproductive ADAMs in mouse. Biol Reprod 74: 744-50.

KONDOH, G., TOJO, H., NAKATANI, Y., KOMAZAWA, N., MURATA, C YAMAGATA, K., MAEDA, Y., KINOSHITA, T., OKABE, M., TAGUCHI, R. et al. (2005). Angiotensin-converting enzyme is a GPI-anchored protein releasing factor crucial for fertilization. Nat Med11: 160-6.

KREGE, J.H., JOHN, S.W., LANGENBACH, L.L., HODGIN, J.B., HAGAMAN, J.R., BACHMAN, E.S., JENNETTE, J.C., O'BRIEN, D.A. and SMITHIES, O. (1995) Male-female differences in fertility and blood pressure in ACE-deficient mice. Nature 375: 146-8.

LAPOINTE, S., SULLIVAN, R. and SIRARD, M.A. (1998). Binding of a bovine oviductal fluid catalase to mammalian spermatozoa. Biol Reprod58: 747-53.

LEBLOND, E., DESNOYERS, L. and MANJUNATH, P. (1993). Phosphorylcholinebinding proteins from the seminal fluids of different species share antigenic determinants with the major proteins of bovine seminal plasma. MolReprod Dev 34: 443-9.

LEFEBVRE, R., CHENOWETH, P.J., DROST, M., LECLEAR, C.T., MACCUBBIN, M., DUTTON, J.T. and SUAREZ, S.S. (1995). Characterization of the oviductal sperm reservoir in cattle. Biol Reprod 53: 1066-74.

LEFEBVRE, R., LO, M.C. and SUAREZ, S.S. (1997). Bovine sperm binding to oviductal epithelium involves fucose recognition. Biol Reprod56: 1198-204.

MANJUNATH, P., SOUBEYRAND, S., CHANDONNET, L. and ROBERTS, K.D. (1994). Major proteins of bovine seminal plasma inhibit phospholipase A2 Biochem J303 (Pt 1): 121-8.

METAYER, S., DACHEUX, F., DACHEUX, J.L. and GATTI, J.L. (2002). Germina angiotensin I-converting enzyme is totally shed from the rodent sperm membrane during epididymal maturation. Biol Reprod67: 1763-7.

MULLER, P., ERLEMANN, K.R., MULLER, K., CALVETE, J.J., TOPFER PETERSEN, E., MARIENFELD, K. and HERRMANN, A. (1998). Biophysical characterization of the interaction of bovine seminal plasma protein PDC-109 with phospholipid vesicles. Eur Biophys J27: 33-41. 
MULLER, P., GREUBE, A., TOPFER-PETERSEN, E. and HERRMANN, A. (2002). Influence of the bovine seminal plasma protein PDC-109 on cholesterol in the presence of phospholipids. Eur Biophys J31: 438-47.

MURRAY, S. C., and SMITH, T. T. (1997). Sperm interaction with Fallopian tube apical plasma membrane enhances sperm motility and delays capacitation. Fertil. Steril. 68: 352-357.

NAUC, V. and MANJUNATH, P. (2000). Radioimmunoassays for bull seminal plasma proteins (BSP-A1/-A2, BSP-A3, and BSP-30-Kilodaltons), and their quantification in seminal plasma and sperm. Biol Reprod63: 1058-66.

NISHIMURA, H., MYLES, D.G. and PRIMAKOFF, P. (2007). Identification of an ADAM2-ADAM3 complex on the surface of mouse testicular germ cells and cauda epididymal sperm. J Biol Chem 282: 17900-7.

OVERSTREET, J.W. and COOPER, G.W. (1978). Sperm transport in the reproductive tract of the female rabbit: II. The sustained phase of transport. Biol Reprod 19: 115-32.

PARRISH, J.J., SUSKO-PARRISH, J., WINER, M.A. and FIRST, N.L. (1988). Capacitation of bovine sperm by heparin. Biol Reprod 38: 1171-80.

PARRISH, J.J., SUSKO-PARRISH, J.L., HANDROW, R.R., SIMS, M.M. and FIRST, N.L. (1989). Capacitation of bovine spermatozoa by oviduct fluid. Bio/ Reprod 40: 1020-5.

POLGE, C., SALAMON, S. and WILMUT, I. (1970). Fertilizing capacity of frozen boar semen following surgical insemination. Vet Rec 87: 424-9.

POLLARD, J.W., PLANTE, C., KING, W.A., HANSEN, P.J., BETTERIDGE, K.J. and SUAREZ, S.S. (1991). Fertilizing capacity of bovine sperm may be maintained by binding of oviductal epithelial cells. Biol Reprod 44: 102-7.

QUILL, T.A., SUGDEN, S.A., ROSSI, K.L., DOOLITTLE, L.K., HAMMER, R.E. and GARBERS, D.L. (2003). Hyperactivated sperm motility driven by CatSper2 is required for fertilization. Proc Nat/ Acad Sci USA 100: 14869-74.

RALT, D., MANOR, M., COHEN-DAYAG, A., TUR-KASPA, I., BEN-SHLOMO, I., MAKLER, A., YULI, I., DOR, J., BLUMBERG, S., MASHIACH, S. et al. (1994). Chemotaxis and chemokinesis of human spermatozoa to follicular factors. Biol Reprod 50: 774-85.

RAMAKRISHNAN, M., ANBAZHAGAN, V., PRATAP, T.V., MARSH, D. and SWAMY, M.J. (2001). Membrane insertion and lipid-protein interactions of bovine seminal plasma protein PDC-109 investigated by spin-label electron spin resonance spectroscopy. Biophys J81: 2215-25.

REN, D., NAVARRO, B., PEREZ, G., JACKSON, A.C., HSU, S., SHI, Q., TILLY, J.L. and CLAPHAM, D.E. (2001). A sperm ion channel required for sperm motility and male fertility. Nature 413: 603-9.

RESCHER, U. and GERKE, V. (2007). S100A10/p11: family, friends and functions. Pflugers Arch.

REVAH, I., GADELLA, B.M., FLESCH, F.M., COLENBRANDER, B. and SUAREZ, S.S. (2000). Physiological state of bull sperm affects fucose- and mannosebinding properties. Biol Reprod62: 1010-5.

SAlUSTRI, A., GARLANDA, C., HIRSCH, E., De ACETIS, M., MACCAGNO, A., BOTTAZZI, B., DONI, A., BASTONE, A., MANTOVANI, G., PECCOZ P.B., SALVATORI, G., MAHONEY, D.J., DAY, A.J., SIRACUSA, G., ROMANI, L., MANTOVANI, A. (2004). PTX3 plays a key role in the organization of the cumulus oophorus extracellular matrix and in in vivo fertilization. Development 131: 1577-1586.

SHAO, C., ZHANG, F., KEMP, M.M., LINHARDT, R.J., WAISMAN, D.M., HEAD, J.F. and SEATON, B.A. (2006). Crystallographic analysis of calcium-dependent heparin binding to annexin A2. J Biol Chem 281: 31689-95.

SMITH, T.T. and NOTHNICK, W.B. (1997). Role of direct contact between spermatozoa and oviductal epithelial cells in maintaining rabbit sperm viability. Biol Reprod 56: 83-9.

SOUBEYRAND, S. and MANJUNATH, P. (1997). Novel seminal phospholipase A2 is inhibited by the major proteins of bovine seminal plasma. Biochim Biophys Acta 1341: 183-8.

SPEHR, M., GISSELMANN, G., POPLAWSKI, A., RIFFELL, J.A., WETZEL, C.H., ZIMMER, R.K. and HATT, H. (2003). Identification of a testicular odorant receptor mediating human sperm chemotaxis. Science 299: 2054-8.

SPEHR, M., SCHWANE, K., RIFFELL, J.A., BARBOUR, J., ZIMMER, R.K., NEUHAUS, E.M. and HATT, H. (2004). Particulate adenylate cyclase plays a key role in human sperm olfactory receptor-mediated chemotaxis. $J$ Biol Chem 279: 40194-203.
STAUSS, C.R., VOTTA, T.J. and SUAREZ, S.S. (1995). Sperm motility hyperactivation facilitates penetration of the hamster zona pellucida. Biol Reprod 53: 1280-5.

SUAREZ, S.S. (1987). Sperm transport and motility in the mouse oviduct: observations in situ. Biol Reprod 36: 203-10.

SUAREZ, S.S., BROCKMAN, K. and LEFEBVRE, R. (1997). Distribution of mucus and sperm in bovine oviducts after artificial insemination: the physical environment of the oviductal sperm reservoir. Biol Reprod56: 447-53.

SUAREZ, S.S. and DAI, X. (1992). Hyperactivation enhances mouse sperm capacity for penetrating viscoelastic media. Biol Reprod 46: 686-91.

SUAREZ, S.S. and HO, H.C. (2003). Hyperactivated motility in sperm. Reprod Domest Anim 38: 119-24.

SUAREZ, S.S., KATZ, D.F., OWEN, D.H., ANDREW, J.B. and POWELL, R.L. (1991b). Evidence for the function of hyperactivated motility in sperm. Biol Reprod 44: 375-81.

SUAREZ, S.S. and OSMAN, R.A. (1987). Initiation of hyperactivated flagellar bending in mouse sperm within the female reproductive tract. Biol Reprod 36: 1191-8.

SUAREZ, S.S., REDFERN, K., RAYNOR, P., MARTIN, F., and PHILLIPS, D.M. (1991a). Attachment of boar sperm to mucosal explants of oviduct in vitro: possible role in formation of a sperm reservoir. Biol. Reprod. 44: 998-1004.

SUAREZ, S.S., REVAH, I., LO, M. and KOLLE, S. (1998). Bull sperm binding to oviductal epithelium is mediated by a $\mathrm{Ca2+-dependent} \mathrm{lectin} \mathrm{on} \mathrm{sperm} \mathrm{that}$ recognizes Lewis-a trisaccharide. Biol Reprod 59: 39-44.

SUAREZ, S.S., VINCENTI, L. and CEGLIA, M.W. (1987). Hyperactivated motility induced in mouse sperm by calcium ionophore A23187 is reversible. J Exp Zool 244: 331-6.

SUN, F., BAHAT, A., GAKAMSKY, A., GIRSH, E., KATZ, N., GIOJALAS, L.C., TURKASPA, I. and EISENBACH, M. (2005). Human sperm chemotaxis: both the oocyte and its surrounding cumulus cells secrete sperm chemoattractants. Hum Reprod20: 761-7.

TAGGART, D.A. (1994). A comparison of sperm and embryo transport in the female reproductive tract of marsupial and eutherian mammals. Reprod Fertil Dev6: 451-72.

THOMAS, P.G., BALL, B.A. and BRINSKO, S.P. (1994). Interaction of equine spermatozoa with oviduct epithelial cell explants is affected by estrous cycle and anatomic origin of explant. Biol Reprod 51: 222-8.

TRESSLER, R.J., UPDYKE, T.V., YEATMAN, T. and NICOLSON, G.L. (1993). Extracellular annexin II is associated with divalent cation-dependent tumor cellendothelial cell adhesion of metastatic RAW117 large-cell lymphoma cells. $J$ Cell Biochem 53: 265-76.

TSAO, F.H., CHEN, X., CHEN, X. and TS'AO, C.H. (1995). Annexin I in female rabbit reproductive organs: varying levels in relation to maturity and pregnancy. Lipids 30: 507-11.

VANDERHAEGHEN, P., SCHURMANS, S., VASSART, G. and PARMENTIER, M. (1993). Olfactory receptors are displayed on dog mature sperm cells. J Cell Biol 123: 1441-52.

WAGNER, A., EKHLASI-HUNDRIESER, M., HETTEL, C., PETRUNKINA, A., WABERSKI, D., NIMTZ, M. and TOPFER-PETERSEN, E. (2002). Carbohydrate-based interactions of oviductal sperm reservoir formation-studies in the pig. Mol Reprod Dev 61: 249-57.

WAH, D.A., FERNANDEZ-TORNERO, C., SANZ, L., ROMERO, A. and CALVETE, J.J. (2002). Sperm coating mechanism from the 1.8 A crystal structure of PDC109-phosphorylcholine complex. Structure (Camb) 10: 505-14.

WALENSKY, L.D., ROSKAMS, A.J., LEFKOWITZ, R.J., SNYDER, S.H. and RONNETT, G.V. (1995). Odorant receptors and desensitization proteins colocalize in mammalian sperm. MolMed1: 130-41.

WILMUT, I. and HUNTER, R.H. (1984). Sperm transport into the oviducts of heifers mated early in oestrus. Reprod Nutr Dev 24: 461-8.

WORTZMAN-SHOW, G.B., KUROKAWA, M., FISSORE, R.A. and EVANS, J.P. (2007). Calcium and sperm components in the establishment of the membrane block to polyspermy: studies of ICSI and activation with sperm factor. Mol Hum Reprod 13: 557-65.

WROBEL, K.H., KUJAT, R. and FEHLE, G. (1993). The bovine tubouterine junction: general organization and surface morphology. Cell Tissue Res 271: 227-39. 
YAMAGATA, K., NAKANISHI, T., IKAWA, M., YAMAGUCHI, R., MOSS, S.B. and OKABE, M. (2002). Sperm from the calmegin-deficient mouse have normal abilities for binding and fusion to the egg plasma membrane. Dev Bio/250: 34857.

YAMAGUCHI, R., YAMAGATA, K., IKAWA, M., MOSS, S.B. and OKABE, M. (2006). Aberrant distribution of ADAM3 in sperm from both angiotensin-converting enzyme (Ace)- and calmegin (Clgn)-deficient mice. Biol Reprod75: 760-6.

YANAGIMACHI, R. and CHANG, M.C. (1963). Sperm Ascent Through The Oviduct Of The Hamster And Rabbit In Relation To The Time Of Ovulation. J Reprod Fertil6: 413-20.
YANIZ, J.L., LOPEZ-GATIUS, F. and HUNTER, R.H. (2006). Scanning electron microscopic study of the functional anatomy of the porcine oviductal mucosa. Anat Histol Embryo/35: 28-34.

ZAMBONI, L. (1972). Fertilization in the mouse. In 'Biology of Mammalian Fertilization and Implantation'. (Eds K.S. Moghissi and E.S.E. Hafez.) pp. 213-262. (Charles C. Thomas: Springfield. IL).

ZHU, L., YONEDA, M., ZHAO, M., YINGSUNG, W., YOSHIDA, N., KITAGAWA, Y., KAWAMURA, K., SUZUKI, T., KIMATA, K. (2001). Defect in SHAP-hyaluronan complex causes severe female infertility. A study by inactivation of the bikunin gene in mice. J. Biol. Chem. 276: 7693-7696.

\section{Related, previously published Int. J. Dev. Biol. articles}

See our recent Special Issue Developmental Biology in Poland edited by Tarkowski, Maleszewski and Kloc at: http://www.ijdb.ehu.es/web/contents.php?vol=52\&issue=2-3

See our recent Special Issue Ear Development edited by Fernando Giraldez and Bernd Fritzsch at: http://www.ijdb.ehu.es/web/contents. php?vol=51\&issue=6-7

Gene mapping of sperm quality parameters in recombinant inbred strains of mice Aniela Golas, Anna Dzieza, Katarzyna Kuzniarz and Jozefa Styrna Int. J. Dev. Biol. (2008) 52: 287-293

Mammalian oocyte activation: lessons from the sperm and implications for nuclear transfer.

R Alberio, V Zakhartchenko, J Motlik and E Wolf

Int. J. Dev. Biol. (2001) 45: 797-809

Association of egg zona pellucida glycoprotein mZP3 with sperm protein sp56 during fertilization in mice.

$\mathrm{N}$ Cohen and $\mathrm{P} \mathrm{M}$ Wassarman

Int. J. Dev. Biol. (2001) 45: 569-576

Sperm-egg interaction at fertilization: glycans as recognition signals. F Rosati, A Capone, C D Giovampaola, C Brettoni and R Focarelli Int. J. Dev. Biol. (2000) 44: 609-618

Seminal plasma effect on ram spermatozoa studied by partitioning in an aqueous two-phase system.

M Ollero, R Perez-Pe, T Muiño-Blanco and J A Cebrian-Pérez Int. J. Dev. Biol. (1996) 40: S205-S206

2006 ISI ${ }^{\star \star}$ Impact Factor $=3.577^{\star \star}$

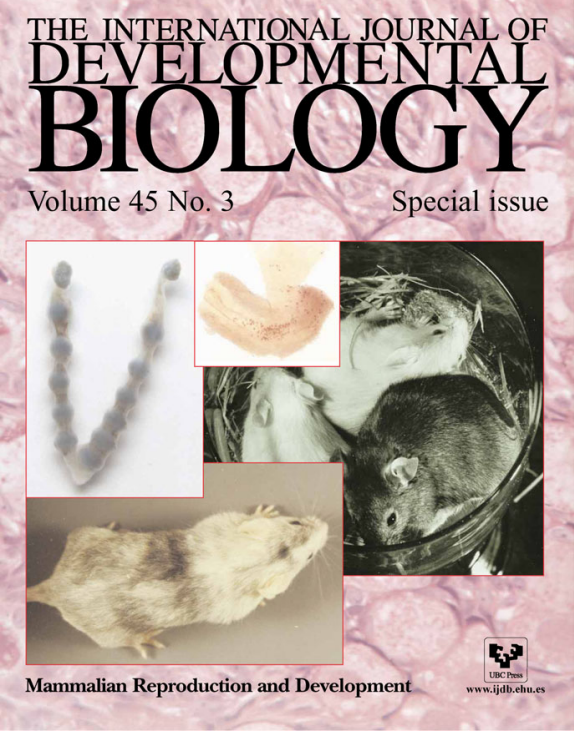

